\title{
CD47 antibody inhibits tumor recurrence in a clinical relevant glioblastoma animal model
}

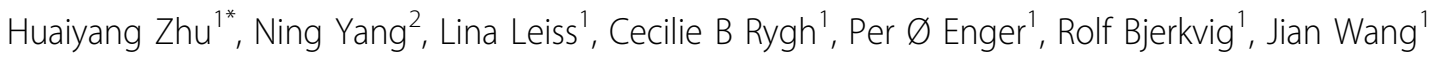 \\ From 30th Annual Meeting and Associated Programs of the Society for Immunotherapy of Cancer (SITC 2015) \\ National Harbor, MD, USA. 4-8 November 2015
}

Glioblastoma multiform (GMB), as a major unsolved clinical challenge, remains among the most aggressive malignan cies in human brain with poor prognosis. Although radiotherapy and chemotherapy that were given to patients after s urgery may improve overall survival, the treatment outcomes in general are poor. Thus, new therapeutic strategy for GBM is urgently needed. CD47, a tumor cell surface marker, plays as "don't eat me signal" through binding its recept or SIRP $\alpha$ on macrophages and the antibody against CD47, which blocks interactions of CD47 with SIRPa, has been shown to lead to tumor destruction1. Furthermore, CD47 is a prognostic marker as its expression predisposes cancer patients to a poorer survival outcome. This has significant clinical implications since approximately more than $80 \%$ of patients with the most GBMs, overexpress CD47. The purpose of the current study is to evaluate the feasibility of tar geting CD47 therapeutically as well as to explore its mechanism in a highly clinical relevant GBM nude rat model. In $t$ he study, we have developed a novel xenograft surgical resection and tumor recurrence GBM model in parallel with $t$ he patient settings in clinic. The model accounted for the therapeutic benefit of surgical resection and demonstrated $t$ hat recurrent tumors higher proliferation and more dilated vessels in comparison with the primary tumors. It also has been shown that the tumor resection recruited more macrophages to the surgical site and by using the anti-CD47 antibody significantly prolonged animal survival. Moreover, angiogenesis array showed the angiogenic factors were down-regulated in the group of the animals treated with CD-47 antibody and cytokines array showed the cytokines that are related to immune responses and antitumor activities were up-regulated by the CD 47 antibody. These results suggest that the presence of

${ }^{1}$ University of Bergen, Bergen, Norway

Full list of author information is available at the end of the article macrophages postoperatively was needed to mediate the anti-tumor effects of the anti-CD47 antibody and CD47 is the potential therapeutic target for recurrent GBM.

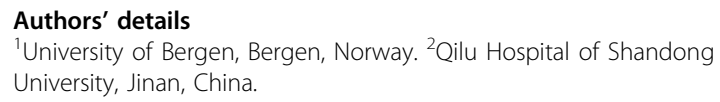

Published: 4 November 2015

doi:10.1186/2051-1426-3-S2-P249

Cite this article as: Zhu et al:: CD47 antibody inhibits tumor recurrence

in a clinical relevant glioblastoma animal model. Journal for ImmunoTherapy of Cancer 2015 3(Suppl 2):P249.

Submit your next manuscript to BioMed Central and take full advantage of:

- Convenient online submission

- Thorough peer review

- No space constraints or color figure charges

- Immediate publication on acceptance

- Inclusion in PubMed, CAS, Scopus and Google Scholar

- Research which is freely available for redistribution

Submit your manuscript at www.biomedcentral.com/submit
() Biomed Central 